\title{
Groundwater Assessment of Hand Dug Wells around Open Landfill in Ibadan Metropolis for Domestic and Irrigation Purposes
}

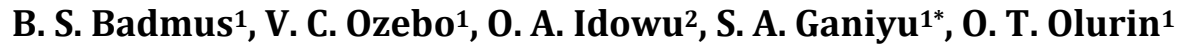 \\ ${ }^{1}$ Department of Physics, Federal University of Agriculture, Abeokuta, Nigeria \\ ${ }^{2}$ Department of Water Resources and Agrometeorology, Federal University of Agriculture, Abeokuta, Nigeria \\ Email: adekunsa@yahoo.com
}

Received 14 September 2014; revised 11 October 2014; accepted 5 November 2014

Copyright @ 2014 by authors and Scientific Research Publishing Inc.

This work is licensed under the Creative Commons Attribution International License (CC BY). http://creativecommons.org/licenses/by/4.0/

c) (i) Open Access

\section{Abstract}

Geochemical assessment of groundwater samples from hand-dug wells within the vicinity of AbaEku dumpsite was carried out for domestic and irrigation purposes. Ten groundwater samples were collected both in dry season and wet season for analysis of physico-chemical parameters: $\mathbf{p H}$, EC, TDS, $\mathrm{Na}^{+}, \mathrm{K}^{+}, \mathrm{Ca}^{2+}, \mathrm{Mg}^{2+}, \mathrm{HCO}_{3}^{-}, \mathrm{CO}_{3}^{2-}, \mathrm{Cl}^{-}, \mathrm{SO}_{4}^{2-}$ and $\mathrm{NO}_{3}^{-}$. The results of the analyses showed the groundwater samples to be within limits of WHO/NSDWQ. However, higher values of concentrations of the chemical constituents were noticed in well 5 nearer to the landfill. Interpretation of Piper diagram showed $\mathrm{CaHCO}_{3}$ to be dominant in the area. Alkaline earth metals $\left(\mathrm{Ca}^{2+}, \mathrm{Mg}^{2+}\right)$ and weak acids $\left(\mathrm{HCO}_{3}^{-}, \mathrm{CO}_{3}^{2-}\right)$ are dominant cations and anions over the alkalis and strong acids in both sessions. Groundwater in the study area is of hard, fresh and alkaline nature. Assessment for irrigation purpose showed that most of the water samples were suitable for irrigation purpose except in a few locations.

\section{Keywords}

Physicochemical Parameters, Irrigation, Groundwater, Freshwater, Hydrochemical Analyses

\section{Introduction}

The quality of water is of vital importance to mankind since it is directly linked with human health. The quality of groundwater is equally important to its quantity due to the suitability of water for various purposes ranging from

*Corresponding author.

How to cite this paper: Badmus, B.S., Ozebo, V.C., Idowu, O.A., Ganiyu, S.A. and Olurin, O.T. (2014) Groundwater Assessment of Hand Dug Wells around Open Landfill in Ibadan Metropolis for Domestic and Irrigation Purposes. Journal of Water Resource and Protection, 6, 1412-1424. http://dx.doi.org/10.4236/jwarp.2014.615130 
drinking, domestic, industrial and agricultural purposes all over the world [1]. The quality of groundwater in a particular region is a function of physical, chemical and biological parameters. According to [2], groundwater quality depends on the quality of recharged water, quantity and quality of generated waste, sewage treatment and subsurface geochemical processes. The variation of groundwater quality in an area is a function of physical and chemical parameters that are greatly influenced by geological formations and anthropogenic activities [1]. Groundwater contamination has become a great problem due to rapid growth of population, industrialization and urbanization rate in the metropolitan city all over the world. Quality of groundwater is normally characterized by different physicochemical parameters level. These parameters change widely due to various types of pollution, seasonal variation and groundwater extraction [3]. Sitting of open dumpsite near the residential areas can have adverse effect on nearby water sources if the leachate emanated from decomposed solid waste infiltrate and pollute the water table. Hydrochemical study reveals the quality of water suitable for domestic and agricultural purpose. Further, it is possible to understand the change in quality due to rock water interaction or any type of anthropogenic influence [4].

Several researchers have identified contamination plumes from disposal sites [5]-[7] with most of these studies focusing on defining the spatial extent of groundwater pollution based on geochemical analysis results. However, the investigation of the suitability of groundwater collected from hand-dug wells within the vicinity of open dumpsite for irrigation needs was not included. [1] have studied groundwater quality and its suitability for drinking and agricultural use in Chithar River Basin, Tamil, Nadu, India. The quality of groundwater in Tarkwa Gold mining area in Ghana was assessed by [8]. [9] carried out hydrochemical analysis and evaluation of groundwater quality in Tumkur Taluk, Karnataka, India for the suitability of water for irrigation purpose. [10] evaluated the suitability of local groundwater quality for domestic and irrigation purposes in Periyakulam Taluk of Theni district, Tamil Nadu India. [11] have also studied groundwater and its suitability for irrigation in the southeastern part of the Ranga Reddy district, Andrapradesh, India.

The present study was carried out for both dry and wet seasons from hand-dug wells bordering Aba-Eku landfill for better understanding of spatial and seasonal distribution of hydrogeochemical constituents of groundwater as well as its suitability for domestic and irrigation purposes.

\section{Location of the Study Area}

Ibadan lies approximately within the square of longitudes $3^{\circ} 35^{\prime} \mathrm{E}$ and $4^{\circ} 10^{\prime} \mathrm{E}$ and latitude $7^{\circ} 20^{\prime} \mathrm{N}$ and $7^{\circ} 40^{\prime} \mathrm{N}$. The study area, Aba Eku located within Ibadan metropolis and located on longitude 3 $59^{\circ} 009 " \mathrm{E}$ and $3^{\circ} 59^{\prime} 973^{\prime \prime} \mathrm{E}$ and latitude $7^{\circ} 19^{\prime} 270 " \mathrm{~N}$ and $7^{\circ} 19^{\prime} 843^{\prime \prime} \mathrm{N}$. The dumpsite is bothered by residential buildings. The study area falls within the humid and subhumid tropical climate of southwestern Nigeria with a mean annual rainfall of about $1230 \mathrm{~mm}$ and mean maximum temperature of $32^{\circ} \mathrm{C}$. Relief in Ibadan is gently undulating and ranges between 200 - $234 \mathrm{~m}$ (above mean sea level). Aba-Eku landfill is one of the four designated open dumpsites managed and maintained by Oyo State Waste Management Authority. It was opened in 1998 and is still active till date. It is located along Ijebu Igbo road covering an area of approximately 10 hecatares.

Geologically, the study area lies within the basement complex rock (Figure 1) characterized by crystalline rocks of Precambrian age with the main rock types comprising quartzites, banded gneiss, augen gneisses and migmatites while the minor ones include pegmatitic intrusion, quartz veins and dolerite dykes [12].

\section{Materials and Methods}

Ten groundwater samples were collected during March and August 2013 at ten different locations from handdug wells around the dumpsite (Figure 2). The distance of the hand-dug wells to the landfill, depth of the well and depth to static water level for both seasons were shown in Table 1. The samples were collected in precleaned and sterilized $2 \mathrm{~L}$ polyethylene bottles. Parameters such as $\mathrm{pH}$, TDS and EC were determined on sites with the aid of multipurpose conductivity meter. Other parameters of interest analyzed in the laboratory were $\mathrm{Ca}^{2+}, \mathrm{Mg}^{2+}, \mathrm{Na}^{+}, \mathrm{K}^{+}, \mathrm{TH}, \mathrm{HCO}_{3}^{-}, \mathrm{Cl}^{-}, \mathrm{SO}_{4}^{2-}$ and $\mathrm{NO}_{3}^{-}$using standard procedures recommended by APHA (1998). Concentrations of $\mathrm{Na}^{+}$and $\mathrm{K}^{+}$were determined using flame photometric method, $\mathrm{HCO}_{3}^{-}$, $\mathrm{CO}_{3}^{2-}$ and $\mathrm{Cl}^{-}$with titrimetric method, $\mathrm{NO}_{3}^{-}$by UV spectrophotometric method while $\mathrm{SO}_{4}^{2-}$ amount was determined using turbidimetric method. The absorption mode of Atomic Absorption Spectrophotometric (AAS) method was used for the determination of $\mathrm{Ca}^{2+}$ and $\mathrm{Mg}^{2+}$ concentrations while total hardness (TH) was determined by Ethy- 


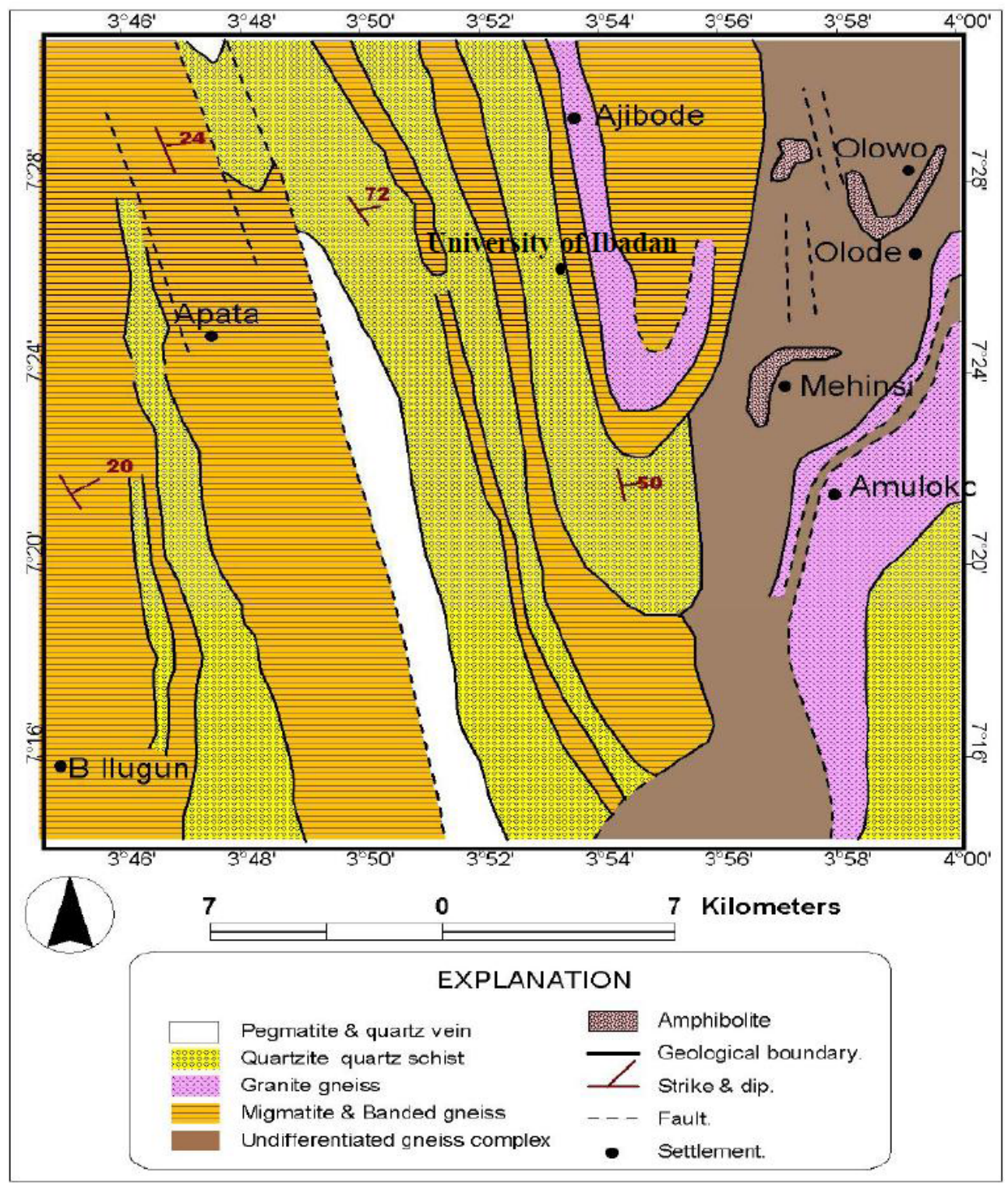

Figure 1. Generalized geological map of Ibadan (after [13]).

lene Diamine Tetra Acetic Acid (EDTA) titration method using Eriochrome black-T as an indicator. The analytical data can be used for the classification of water for various purposes and their percentage compliance with the World Health Organization (WHO) as well as Nigerian Standard for Driking Water Quality (NSDWQ).

\section{Results and Discussion}

Maximum and minimum concentrations of major ions present in the water samples and their percentage compliance with WHO and NSDWQ limits for both dry and wet seasons are as shown in Table 2, while Table 3 shows the comparison between values of each parameter during dry and wet seasons sampling periods.

The $\mathrm{pH}$ values of groundwater range from 6.69 to 7.59 and 6.51 to 7.06 during dry and wet seasons respectively. The $\mathrm{pH}$ values during both seasons fall within the WHO and NSDWQ permissible range of 6.5 - 8.5. Fifty percentage of analyzed samples have $\mathrm{pH}$ values below 7.0 during dry season while this increase to $80 \%$ during wet season. This indicates that there is more dissolution of pollutants during the rainy season. The total Hardness (TH) values during dry and wet seasons ranged from 08 to $288 \mathrm{mg} / \mathrm{L}$ and from 132 to $446 \mathrm{mg} / \mathrm{L}$ respectively. Based on [14] classification, $40 \%$ of samples fall under the "soft" class, $50 \%$ under "moderate" class 


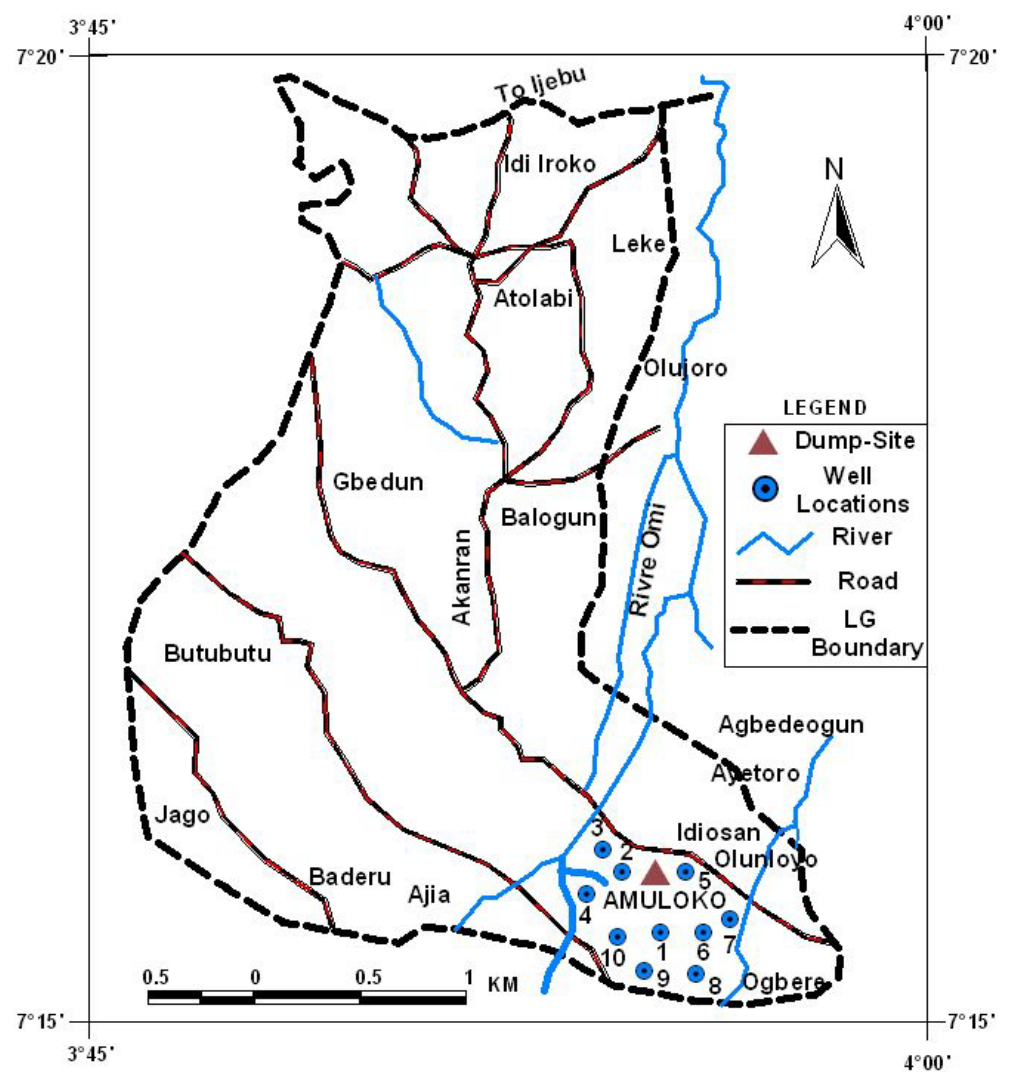

Figure 2. Map of Aba Eku showing the Dumpsite and water samples locations.

Table 1. Well parameter for Aba-Eku water samples (dry and wet season).

\begin{tabular}{ccccc}
\hline Well & Distance to landfill $(\mathbf{m})$ & Depth to water table $(\mathbf{m}) \mathbf{( D r y})$ & Depth to water table (m) $($ Wet) & Depth to bottom (m) \\
\hline 1. & 110.00 & 5.90 & 4.00 & 7.30 \\
2. & 30.00 & 6.60 & 4.30 & 13.40 \\
3. & 50.00 & 5.50 & 3.30 & 10.90 \\
4. & 50.00 & 6.40 & 2.50 & 10.90 \\
5. & 20.00 & 3.00 & 3.50 & 5.40 \\
6. & 350.00 & 2.50 & 2.40 & 5.40 \\
7. & 5.50 & 3.60 & 6.00 \\
8. & 360.00 & 4.30 & 2.90 & 7.30 \\
9. & 360.00 & 4.30 & 2.60 & 7.00 \\
10. & 170.00 & 0.90 & 1.50 & 4.20 \\
\hline
\end{tabular}

while $10 \%$ falls under "Hard" class during the dry season. During wet season of sample collection, none falls under "soft" class of hardness, $10 \%$ fall under "moderate" class, $70 \%$ fall under "Hard" class while the remaining 20\% fall under "very hard" class. The chloride ion concentration values ranged from 17 to $106 \mathrm{mg} / \mathrm{L}$ and 10 to $120 \mathrm{mg} / \mathrm{L}$ during dry and wet seasons respectively and these were found to lie within the permissible level of $250 \mathrm{mg} / \mathrm{L}$. The nitrate values during dry season ranged from 1.4 to $4.8 \mathrm{mg} / \mathrm{L}$. However, during wet season, it ranged from 0 to $3.3 \mathrm{mg} / \mathrm{L}$. Unpolluted natural water usually contains only minute quantities of nitrate. The groundwater samples in both seasons have their nitrate values lie below the limit of $50 \mathrm{mg} / \mathrm{L}$ by WHO and 
Table 2. Comparison of groundwater quality parameters of Aba-Eku with drinking water standards (dry and wet season).

\begin{tabular}{|c|c|c|c|c|c|c|c|}
\hline \multirow{2}{*}{ Parameters } & \multicolumn{2}{|c|}{ Range (Dry) } & \multirow{2}{*}{ Percent compliance } & \multicolumn{2}{|c|}{ Range (Wet) } & \multirow{2}{*}{ Percent compliance } & \multirow{2}{*}{ [16] \& [17] } \\
\hline & Min & Max & & Min & Max & & \\
\hline $\mathrm{pH}$ & 6.69 & 7.59 & 100 & 6.51 & 7.06 & 100 & $6.5-8.5$ \\
\hline EC & 148 & 784 & 100 & 202 & 539 & 100 & 1000 \\
\hline TDS & 74 & 392 & 100 & 1000 & 268 & 100 & 500 \\
\hline $\mathrm{Cl}^{-}$ & 17 & 106 & 100 & 10 & 120 & 100 & 250 \\
\hline $\mathrm{HCO}_{3}^{-}$ & 122 & 366 & 100 & 146.4 & 414.8 & 100 & 1000 \\
\hline $\mathrm{CO}_{3}^{2-}$ & 60 & 180 & 90 & 72 & 204 & 70 & 120 \\
\hline $\mathrm{TH}$ & 08 & 288 & 90 & 132 & 446 & 10 & 150 \\
\hline $\mathrm{Na}^{+}$ & 08 & 40 & 100 & 11 & 26 & 100 & 200 \\
\hline $\mathrm{K}^{+}$ & 0 & 5 & 100 & 1 & 4 & 100 & 55 \\
\hline $\mathrm{NO}_{3}^{-}$ & 1.36 & 4.81 & 100 & 0 & 3.27 & 100 & 50 \\
\hline $\mathrm{Ca}^{2+}$ & 0.12 & 5.87 & 100 & 1.62 & 15.09 & 100 & 75 \\
\hline $\mathrm{Mg}^{2+}$ & 0.43 & 14.78 & 100 & 4.18 & 26.2 & 100 & 50 \\
\hline $\mathrm{SO}_{4}^{2-}$ & 13.39 & 144.03 & 100 & 10.32 & 75.32 & 100 & 250 \\
\hline
\end{tabular}

Table 3. Physiochemical parameters during dry and wet season for Aba-Eku water samples.

\begin{tabular}{|c|c|c|c|c|c|c|c|c|c|c|c|c|c|c|c|c|c|c|c|c|c|c|c|c|c|c|}
\hline \multirow{2}{*}{ Sample } & \multicolumn{2}{|c|}{$\mathrm{pH}$} & \multicolumn{2}{|c|}{ EC } & & & \multicolumn{2}{|c|}{$\mathrm{HCO}_{3}^{-}$} & \multicolumn{2}{|c|}{$\mathrm{CO}_{3}^{2-}$} & & & \multicolumn{2}{|c|}{$\mathrm{K}^{+}$} & \multicolumn{2}{|c|}{$\mathrm{SO}_{4}^{2-}$} & \multicolumn{2}{|c|}{$\mathrm{NO}_{3}^{-}$} & \multicolumn{2}{|c|}{$\mathrm{Mg}^{2+}$} & \multicolumn{2}{|c|}{$\mathrm{Ca}^{2+}$} \\
\hline & Dry & Wet & Dry & Wet & Dry & Wet & Dry & Wet & Dry & Wet & Dry & Wet & Dry & Wet & Dry & Wet & Dry & Wet & Dry & Wet & Dry & Wet & Dry & Wet & Dry & Wet \\
\hline $\mathrm{S}_{2}$ & 7.1 & 6.9 & 381 & 511 & 190 & 254 & 68 & 41.5 & 170.8 & 195.2 & 84 & 96 & 78 & 320 & 30 & 26 & 1 & 1 & 15.65 & 12.10 & 1.6 & 0 & 5.59 & 15.63 & 0.79 & 2.80 \\
\hline $\mathrm{S}_{3}$ & 6.7 & 6.5 & 227 & 253 & 113 & 130 & 20 & 13 & 219.6 & 195.2 & 108 & 96 & 84 & 222 & 15 & 12 & 1 & 2 & 14.19 & 10.65 & 1.6 & 0 & 9.32 & 11.93 & 2.02 & 6.27 \\
\hline $\mathrm{S}_{4}$ & 6.8 & 6.7 & 240 & 315 & 120 & 156 & 25 & 19.5 & 219.6 & 244 & 108 & 120 & 90 & 266 & 15 & 15 & 1 & 1 & 13.39 & 12.42 & 1.4 & 0.4 & 7.05 & 10.67 & 1.73 & 9.40 \\
\hline $\mathrm{S}_{5}$ & 6.7 & 6.9 & 784 & 539 & 392 & 268 & 106 & 120 & 366 & 390.4 & 180 & 192 & 288 & 446 & 40 & 24 & 5 & 4 & 144.03 & 75.32 & 2.8 & 0.2 & 14.78 & 26.24 & 5.87 & 15.09 \\
\hline $\mathrm{S}_{6}$ & 6.9 & 7.1 & 231 & 233 & 115 & 116 & 25 & 16 & 170.8 & 219.6 & 84 & 108 & 08 & 154 & 18 & 16 & 1 & 1 & 15.00 & 15.32 & 1.5 & 0.2 & 2.69 & 5.08 & 0.94 & 5.58 \\
\hline $\mathrm{S}_{7}$ & 7.3 & 6.8 & 176 & 237 & 88 & 118 & 25 & 17 & 146.4 & 195.2 & 72 & 96 & 26 & 132 & 13 & 17 & 0 & 1 & 14.19 & 24.52 & 2.8 & 3.3 & 0.43 & 4.18 & 0.12 & 2.22 \\
\hline $\mathrm{S}_{9}$ & 6.9 & 6.8 & 263 & 229 & 131 & 113 & 26 & 15.5 & 219.6 & 195.2 & 108 & 96 & 116 & 216 & 12 & 12 & 1 & 1 & 42.42 & 22.26 & 1.9 & 0 & 12.31 & 11.28 & 4.17 & 7.53 \\
\hline $\mathrm{S}_{10}$ & 7.1 & 6.5 & 148 & 202 & 74 & 100 & 19 & 16 & 122 & 146.4 & 60 & 72 & 60 & 174 & 8 & 11 & 1 & 1 & 26.13 & 21.77 & 4.8 & 1.2 & 4.36 & 8.87 & 0.59 & 3.47 \\
\hline
\end{tabular}

NSDWQ. The values of sulphate ions in the groundwater samples ranged from 13.4 to $144 \mathrm{mg} / \mathrm{L}$ during dry season and 10.3 to $75.3 \mathrm{mg} / \mathrm{L}$ during wet season. However, sulphate lie below $200 \mathrm{mg} / \mathrm{L}$ according to WHO and NSDWQ limit. The $\mathrm{Na}^{+}$and $\mathrm{K}^{+}$values ranged from 08 to $40 \mathrm{mg} / \mathrm{L}$ and 0 to $5 \mathrm{mg} / \mathrm{L}$ during dry season and lie below the limits set by WHO and NSDWQ. During wet season, $\mathrm{Na}^{+}$and $\mathrm{K}^{+}$values ranged from 11 to $26 \mathrm{mg} / \mathrm{L}$ and 01 to $4 \mathrm{mg} / \mathrm{L}$ respectively. The low pottassium concentrations in both seasons compared to $\mathrm{Na}^{+}$concentration may be due to the resistant of potassium minerals to decomposition by weathering process. Also its low concentration in natural water is as a consequence of its tendency to be fixed by clay minerals and participate in the formation of secondary minerals.

The $\mathrm{Ca}^{2+}$ and $\mathrm{Mg}^{2+}$ concentration values during dry and wet seasons ranged from 0.1 to $5.9 \mathrm{mg} / \mathrm{L} ; 0.4$ to 14.8 $\mathrm{mg} / \mathrm{L}$ and 1.6 to $15.1 \mathrm{mg} / \mathrm{L} ; 4.2$ to $26.2 \mathrm{mg} / \mathrm{L}$ respectively. 
The EC values range from $148 \mu \mathrm{S} / \mathrm{cm}$ to $784 \mu \mathrm{S} / \mathrm{cm}$ during dry season and $202 \mu \mathrm{S} / \mathrm{cm}$ to $539 \mu \mathrm{S} / \mathrm{cm}$ during wet season. The TDS values lie within the WHO and NSDWQ limits. The TDS values in both seasons showed that all the water samples irrespective of the season belong to "freshwater" class based on [15] classifications as presented in Table 4.

The abundance of major ions in groundwater during both seasons is in the following order: $\mathrm{Na}^{+}>\mathrm{Mg}^{2+}>$ $\mathrm{Ca}^{2+}>\mathrm{K}^{+}$and $\mathrm{HCO}_{3}^{-}>\mathrm{CO}_{3}^{2-}>\mathrm{Cl}^{-}>\mathrm{SO}_{4}^{2-}>\mathrm{NO}_{3}^{-}$. It was observed that higher values of concentrations of most parameters were noticed in well 5 during both seasons. This may be attributed to close proximity of well 5 to Aba Eku dumpsite (20 m distance to the landfill).

The degree of a linear association between any two analyzed parameters measured by Pearson's Correlation coefficient for both dry and wet seasons are presented in Table 5 and Table 6 respectively. There is a strong association between $E C$ and TDS, $\mathrm{Cl}^{-}, \mathrm{TH}$ and $\mathrm{Na}^{+}$during both sampling periods. This confirmed the fact that EC depends largely on the quality of the dissolved salts present in the sample.

\subsection{Hydrochemical Analyses}

Hydrochemical concept can help to elucidate the mechanism of flow and transport in groundwater systems [18]. The geochemical evolution of groundwater can be understood by plotting the concentration of major cations and anions in the [19]. The classification for cation and anions in terms of major ion percentage and water type is according to the domain in which they occur in the diagram segment [20]. The plot shows that most of the groundwater samples analyzed during both seasons are of $\mathrm{Cl}^{-}, \mathrm{CaHCO}_{3}$ type. From the plot, alkaline earth $\left(\mathrm{Ca}^{2+}\right.$ and $\left.\mathrm{Mg}^{2+}\right)$ exceed the alkali's $\left(\mathrm{Na}^{+}\right.$and $\mathrm{K}^{+}$) while the weak acids $\left(\mathrm{HCO}_{3}^{-}\right.$and $\mathrm{CO}_{3}^{2-}$ ) exceed the strong acids $\left(\mathrm{Cl}^{-}\right.$and $\mathrm{SO}_{4}^{2-}$ ) in both seasons (Figure 3). The freshwater status of analyzed water samples in both seasons is due to the geology of basement complex rock while dominance of weak acid types in the groundwater suggests carbonate mineral dissolution in the groundwater.

\subsection{Suitability of Groundwater for Irrigation Purpose}

Good quality irrigation water is essential for proper growth of crop plants. Groundwater suitability for irrigation purpose in this study was assessed using various irrigation parameters. The irrigation parameters are Sodium Adsorption Ratio (SAR), Percentage Sodium (\%Na), Residual Sodium BiCarbonate (RSBC), Magnessium Ratio (MAR), Kelly's Ratio (KR) and Permeability Index (PI). The results of these irrigation parameters in both seasons are presented in Table 7 and Table 8.

Wilcox (1948) classified groundwater for irrigation purposes based on \%Na and Electrical conductivity.

The sodium in irrigation water in usually denoted as \% Na and can be determined using the formula:

$$
\% \mathrm{Na}=\frac{\left(\mathrm{Na}^{+}\right) \times 100}{\left(\mathrm{Ca}^{2+}+\mathrm{Mg}^{2+}+\mathrm{Na}^{+}+\mathrm{K}^{+}\right)}
$$

where the quantities are expressed in Meq/L. The classification of analyzed water samples is shown in Table 9 based on \%Na values.

Salinity: Electrical conductivity (EC) is a measure of the amount of dissolved salts present in groundwater samples. EC is a good measure of salinity hazard to crops as it reflects the TDS in groundwater [1]. Based on EC values, $70 \%$ fall under "Excellent" class for irrigation purpose while 30\% fall under "Good" class during dry season. In wet season, the classification of water samples with respect to EC values shows $50 \%$ in "Excellent" class while the remaining $50 \%$ belong to "Good" class for irrigation purpose. Excess salinity reduces the osmotic

\begin{tabular}{ccc|}
\hline \multicolumn{3}{|c|}{ Table 4. Nature of groundwater based on TDS value. } \\
\hline TDS $\mathbf{~ m g} / \mathbf{L}$ & Class & \% compliance \\
\hline $0-1000$ & Freshwater & 100 \\
$1000-10,000$ & Brackish & - \\
$10,000-100,000$ & Saline water & - \\
$>100,000$ & Brine & - \\
\hline
\end{tabular}


Table 5. Correlation coefficient of Aba-Eku water samples parameters during dry season.

\begin{tabular}{|c|c|c|c|c|c|c|c|c|c|c|c|c|c|}
\hline & pH & EC & TDS & $\mathrm{Cl}^{-}$ & Bicarbonate & Hardness & Carbonate & $\mathrm{SO}_{4}^{2-}$ & $\mathrm{NO}_{3}^{-}$ & $\mathrm{Na}^{+}$ & $\mathbf{K}^{+}$ & $\mathbf{M g}^{2+}$ & $\mathrm{Ca}^{2+}$ \\
\hline $\mathrm{pH}$ & 1 & & & & & & & & & & & & \\
\hline EC & -0.446 & 1 & & & & & & & & & & & \\
\hline TDS & -0.447 & $1.000\left(^{* *}\right)$ & 1 & & & & & & & & & & \\
\hline $\mathrm{Cl}^{-}$ & -0.419 & $0.955\left(^{* *}\right)$ & $0.955\left(^{* *}\right)$ & 1 & & & & & & & & & \\
\hline Bicarbonate & -0.551 & $0.886\left(^{* *}\right)$ & $0.886\left(^{* *}\right)$ & $0.730\left(^{*}\right)$ & 1 & & & & & & & & \\
\hline Hardness & -0.423 & $0.903\left(^{* *}\right)$ & $\left.0.9033^{* *}\right)$ & $0.787\left(^{* *}\right)$ & $0.922\left(^{* *}\right)$ & 1 & & & & & & & \\
\hline Carbonate & -0.551 & $0.886\left(^{* *}\right)$ & $0.886\left(^{* *}\right)$ & $0.730\left(^{*}\right)$ & $1.000\left(^{* *}\right)$ & $0.922\left(^{* *}\right)$ & 1 & & & & & & \\
\hline $\mathrm{SO}_{4}^{2-}$ & -0.400 & $0.917\left(^{* *}\right)$ & $0.917\left(^{* *}\right)$ & $0.815\left(^{* * *}\right)$ & $0.867\left(^{* *}\right)$ & $0.935\left(^{* *}\right)$ & $0.867\left(^{* *}\right)$ & 1 & & & & & \\
\hline $\mathrm{NO}_{3}^{-}$ & 0.471 & -0.060 & -0.059 & -0.089 & -0.185 & 0.102 & -0.185 & 0.187 & 1 & & & & \\
\hline $\mathrm{Na}^{+}$ & -0.425 & $0.923\left(^{* *}\right)$ & $0.922\left(^{* *}\right)$ & $0.966\left(^{* *}\right)$ & $0.716\left(^{*}\right)$ & $0.703\left(^{*}\right)$ & $0.716\left(^{*}\right)$ & $0.719\left(^{*}\right)$ & -0.264 & 1 & & & \\
\hline $\mathrm{K}^{+}$ & -0.460 & $0.897\left(^{* *}\right)$ & $0.897\left(^{* *}\right)$ & $0.808\left(^{* * *}\right)$ & $0.847\left(^{* *}\right)$ & $0.900\left(^{* * *}\right)$ & $0.847\left(^{* *}\right)$ & $0.924\left(^{* *}\right)$ & 0.043 & $0.782\left(^{* *}\right)$ & 1 & & \\
\hline $\mathrm{Mg}^{2+}$ & $-0.646\left(^{*}\right)$ & $0.670\left(^{*}\right)$ & $\left.0.670^{*}\right)$ & 0.547 & $0.818\left(^{* *}\right)$ & $0.834\left(^{* *}\right)$ & $0.818\left(^{* *}\right)$ & $\left.0.710^{*}\right)$ & -0.216 & 0.500 & $0.733\left(^{*}\right)$ & 1 & \\
\hline $\mathrm{Ca}^{2+}$ & -0.175 & $0.665\left(^{*}\right)$ & $0.664\left({ }^{*}\right)$ & 0.462 & $0.815\left(^{* *}\right)$ & $0.842\left(^{* *}\right)$ & $0.815\left(^{* *}\right)$ & $0.764\left(^{*}\right)$ & 0.053 & 0.424 & $0.751\left(^{*}\right)$ & $0.807\left(^{* *}\right)$ & 1 \\
\hline
\end{tabular}

${ }^{* *}$ Correlation is significant at the 0.01 level (2-tailed). ${ }^{*}$ Correlation is significant at the 0.05 level (2-tailed).

Table 6. Correlation coefficient of Aba-Eku water samples parameters during wet season.

\begin{tabular}{|c|c|c|c|c|c|c|c|c|c|c|c|c|}
\hline & pH & EC & TDS & $\mathrm{Cl}^{-}$ & $\mathrm{CO}_{3}^{2-}$ & $\mathrm{HCO}_{3}^{-}$ & Hardness & $\mathrm{SO}_{4}^{2-}$ & $\mathrm{NO}_{3}^{-}$ & $\mathrm{Na}^{+}$ & $\mathbf{K}^{+}$ & $\mathrm{Mg}^{2+} \mathrm{Ca}^{2+}$ \\
\hline $\mathrm{pH}$ & 1 & & & & & & & & & & & \\
\hline EC & 0.224 & 1 & & & & & & & & & & \\
\hline TDS & 0.217 & $1.000\left(^{* *}\right)$ & 1 & & & & & & & & & \\
\hline $\mathrm{Cl}^{-}$ & 0.181 & $0.836\left(^{* *}\right)$ & $0.836\left(^{* *}\right)$ & 1 & & & & & & & & \\
\hline $\mathrm{CO}_{3}^{2-}$ & 0.551 & 0.351 & 0.351 & 0.535 & 1 & & & & & & & \\
\hline $\mathrm{HCO}_{3}^{-}$ & 0.551 & 0.351 & 0.351 & 0.535 & $1.000\left(^{* *}\right)$ & 1 & & & & & & \\
\hline Hardness & 0.051 & $0.916\left(^{* *}\right)$ & $0.916\left(^{* *}\right)$ & $0.882\left(^{* *}\right)$ & 0.396 & 0.396 & 1 & & & & & \\
\hline $\mathrm{SO}_{4}^{2-}$ & 0.163 & 0.548 & 0.546 & $0.906\left(^{* *}\right)$ & 0.613 & 0.613 & $0.650\left(^{*}\right)$ & 1 & & & & \\
\hline $\mathrm{NO}_{3}^{-}$ & -0.272 & -0.276 & -0.279 & -0.156 & -0.318 & -0.318 & -0.417 & 0.019 & 1 & & & \\
\hline $\mathrm{Na}^{+}$ & 0.369 & $0.923\left(^{* *}\right)$ & $0.921\left(^{* *}\right)$ & $0.725\left(^{*}\right)$ & 0.225 & 0.225 & $0.713\left(^{*}\right)$ & 0.451 & -0.038 & 1 & & \\
\hline $\mathrm{K}^{+}$ & -0.045 & 0.630 & $0.636\left(^{*}\right)$ & $0.894\left({ }^{* *}\right)$ & 0.494 & 0.494 & $0.782\left(^{* *}\right)$ & $0.856\left(^{* *}\right)$ & -0.184 & 0.453 & 1 & \\
\hline $\mathrm{Mg}^{2+}$ & -0.075 & $0.850\left(^{* *}\right)$ & $0.852\left(^{* *}\right)$ & $0.896\left(^{* *}\right)$ & 0.314 & 0.314 & $0.962\left(^{* *}\right)$ & $0.716\left(^{*}\right)$ & -0.369 & $0.644\left(^{*}\right)$ & $0.844\left(^{* *}\right)$ & 1 \\
\hline $\mathrm{Ca}^{2+}$ & 0.023 & 0.406 & 0.402 & 0.579 & 0.346 & 0.346 & $0.667\left(^{*}\right)$ & 0.504 & -0.348 & 0.180 & $0.668\left(^{*}\right)$ & 0.593 \\
\hline
\end{tabular}

${ }^{* *}$ Correlation is significant at the 0.01 level (2-tailed). ${ }^{*}$ Correlation is significant at the 0.05 level (2-tailed).

activity of plants and this interferes with the absorption of water and nutrients from the soil [21]. The classification of water samples with respect to EC values are shown in Table $\mathbf{1 0 .}$

Sodium adsorption ratio (SAR): This is a better measurement of sodium hazard present in water. SAR gives an idea about the adsorption of $\mathrm{Na}^{+}$in water by soil. It is an important parameter that is used to evaluate the suitablity of water for irrigation purpose because it is a measure of sodium hazard to crops. SAR is defined by [22] as: 


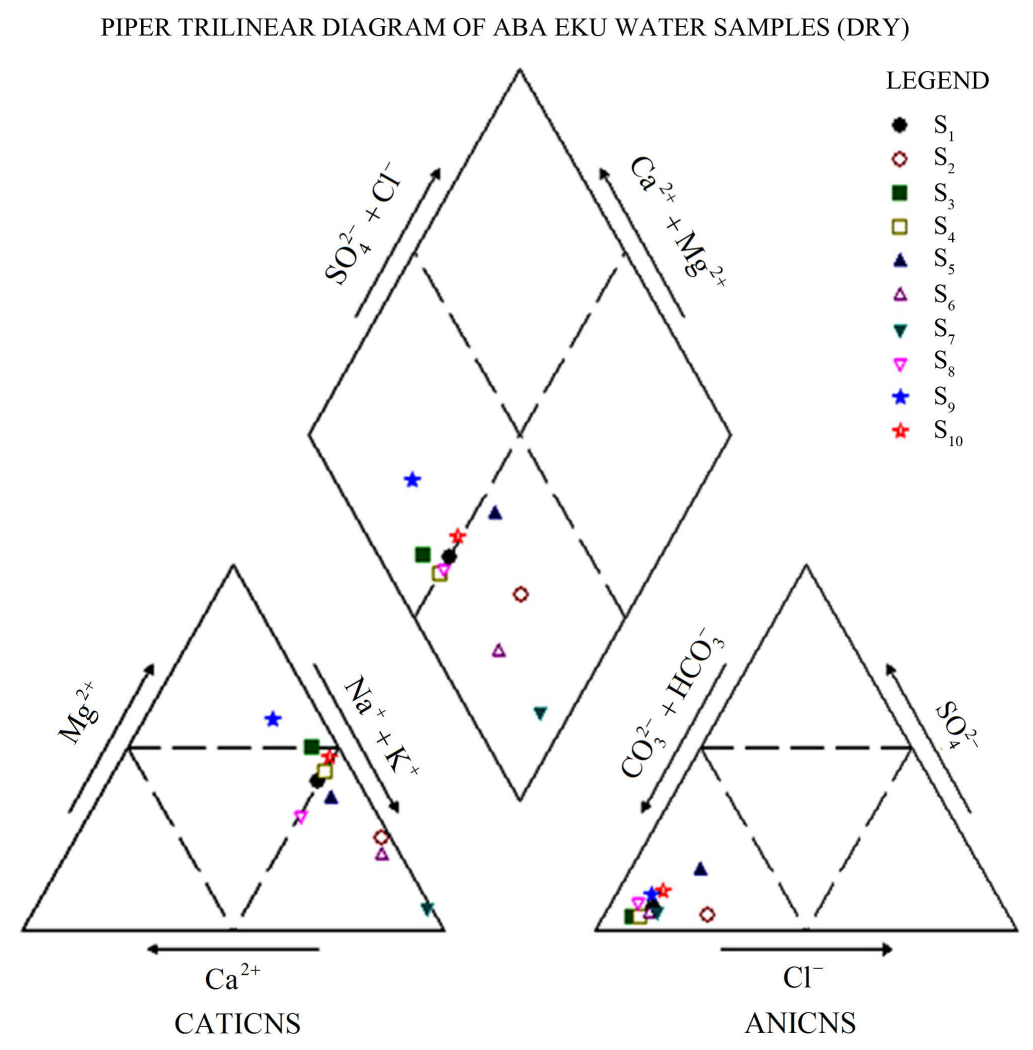

PIPER TRILINEAR DIAGRAM OF ABA EKU WATER SAMPLES (WET)

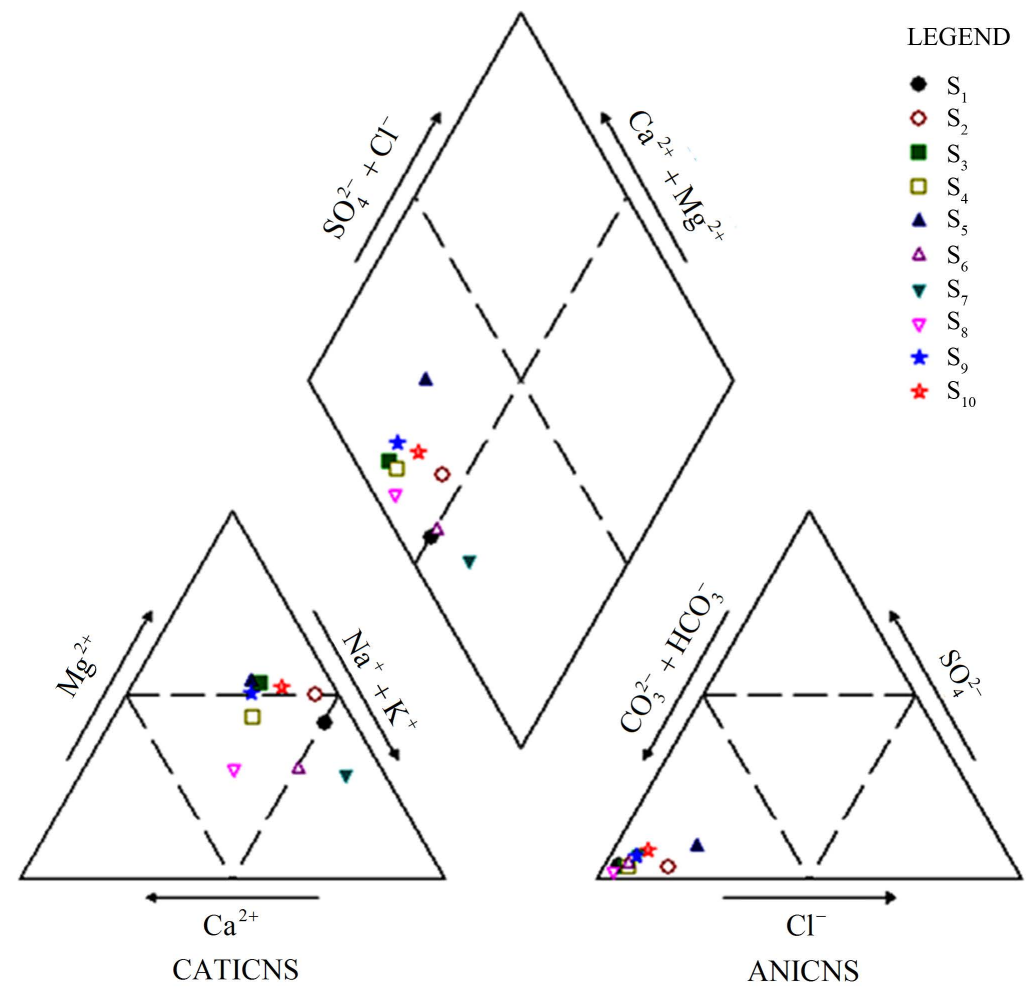

Figure 3. Piper Diagram for Aba-Eku water sample during dry and wet seasons. 
Table 7. Water analysis for irrigation purpose (dry season).

\begin{tabular}{cccccccc}
\hline Sample & SAR & \% Na & Soluble sodium \% & RSBC & MAR & KR & PI \\
\hline $\mathrm{S}_{1}$ & 1.17509 & 46.74 & 49.96 & 2.651 & 81.16 & 0.93 & 157.6 \\
$\mathrm{~S}_{2}$ & 2595057 & 71.06 & 72.47 & 2.761 & 92.27 & 2.58 & 164.5 \\
$\mathrm{~S}_{3}$ & 0.984607 & 41.92 & 43.60 & 3.499 & 88.48 & 0.74 & 116.7 \\
$\mathrm{~S}_{4}$ & 1.122305 & 48.18 & 50.11 & 3.513 & 87.11 & 0.97 & 192.1 \\
$\mathrm{~S}_{5}$ & 1.995426 & 51.36 & 55.14 & 5.706 & 80.65 & 1.14 & 128.5 \\
$\mathrm{~S}_{6}$ & 2.131056 & 72.57 & 74.97 & 2.753 & 82.59 & 2.90 & 233.2 \\
$\mathrm{~S}_{7}$ & 3.89887 & 93.08 & 93.08 & 2.394 & 85.72 & 13.45 & 348.2 \\
$\mathrm{~S}_{8}$ & 1.002734 & 47.88 & 50.28 & 3.003 & 63.65 & 0.96 & 217.2 \\
$\mathrm{~S}_{9}$ & 0.66455 & 29.29 & 30.75 & 3.392 & 83.14 & 0.42 & 137.7 \\
$\mathrm{~S}_{10}$ & 0.786052 & 45.43 & 48.82 & 1.971 & 92.60 & 0.88 & 238.1 \\
\hline
\end{tabular}

Table 8. Water analyses for irrigation purpose (wet season).

\begin{tabular}{ccccccccc}
\hline Sample & SAR & \% Na & Soluble sodium \% & RSBC & MAR & KR & PI \\
\hline $\mathrm{S}_{1}$ & 1.05190 & 48.37 & 50.59 & 6.719 & 85.96 & 0.97 & 277.8 \\
$\mathrm{~S}_{2}$ & 1.33033 & 43.48 & 44.48 & 3.060 & 90.29 & 0.78 & 113.4 \\
$\mathrm{~S}_{3}$ & 0.64523 & 27.74 & 30.45 & 2.886 & 76.01 & 0.39 & 126.2 \\
$\mathrm{~S}_{4}$ & 0.79125 & 32.02 & 33.30 & 3.530 & 65.39 & 0.48 & 131.9 \\
$\mathrm{~S}_{5}$ & 0.86010 & 25.51 & 28.04 & 5.645 & 74.32 & 0.35 & 89.7 \\
$\mathrm{~S}_{6}$ & 1.17394 & 48.84 & 50.66 & 3.321 & 60.31 & 0.99 & 185.4 \\
$\mathrm{~S}_{7}$ & 1.54259 & 60.37 & 62.50 & 3.089 & 75.81 & 1.61 & 211.0 \\
$\mathrm{~S}_{8}$ & 0.77792 & 34.33 & 35.90 & 3.834 & 46.35 & 0.53 & 164.4 \\
$\mathrm{~S}_{9}$ & 0.64327 & 27.98 & 29.38 & 2.823 & 71.37 & 0.39 & 125.6 \\
$\mathrm{~S}_{10}$ & 0.70786 & 33.76 & 35.59 & 2.227 & 81.03 & 0.52 & 145.8 \\
\hline
\end{tabular}

Table 9. Sodium \% water class.

\begin{tabular}{cccc}
\hline Water class & \% Na & \% during dry season & \% during wet season \\
\hline Excellent & $<20$ & - & - \\
Good & $20-40$ & $10 \%$ & $60 \%$ \\
Permissible & $40-60$ & $60 \%$ & $30 \%$ \\
Doubtful & $60-80$ & $20 \%$ & $10 \%$ \\
Unsuitable & $>80$ & $10 \%$ & - \\
\hline
\end{tabular}

$$
\mathrm{SAR}=\frac{\mathrm{Na}^{+}}{\left(\frac{\mathrm{Ca}^{2+}+\mathrm{Mg}^{2+}}{2}\right)^{1 / 2}}
$$

where the concentrations are in Meq/L. 
Table 10. Quality of irrigation water classes based on EC values.

\begin{tabular}{cccc}
\hline Water class & EC values & \% during dry season & \% during wet season \\
\hline Excellent & $<250$ & $70 \%$ & $50 \%$ \\
Good & $250-750$ & $30 \%$ & $50 \%$ \\
Permissible & $750-2000$ & - & - \\
Doubtful & $2000-3000$ & - & - \\
Unsuitable & $>3000$ & - & - \\
\hline
\end{tabular}

High value of $S A R$ means that sodium in water may replace $\mathrm{Ca}^{2+}$ and $\mathrm{Mg}^{2+}$ ions in the soil thereby causing potential damage to the soil structure and affect availability of water to crop [23]. Based on classification by [24], all the analyzed groundwater samples have SAR values less than 10 during dry and wet seasons and are thus classified as "Excellent" for irrigation. This is shown in Table 11.

Permeability Index (PI): The PI values also indicate the suitability of groundwater for irrigation purpose. The influencing constituents for PI values are total dissolved solid, Sodium bicarbonate and the soil type. It is defined as follows [25]:

$$
\mathrm{PI}=\frac{\left(\mathrm{Na}^{+}+\sqrt{\mathrm{HCO}_{3}^{-}}\right) \times 100}{\left(\mathrm{Ca}^{2+}+\mathrm{Mg}^{2+}+\mathrm{Na}^{+}\right)}
$$

where the concentrations are in Meq/L.

From Table 8 and Table 9, the PI values for both seasons fall under "Excellent” class for irrigation purpose. The classification of water samples with respect to PI value is shown in Table 12.

Soluble sodium percentage (SSP): This is an important factor for studying sodium hazards. Sodium has the potential of reacting with soil thereby reducing its permeability and supports little or no plant growth [23]. It is defined [26] as:

$$
\mathrm{SSP}=\frac{\left(\mathrm{Na}^{+}+\mathrm{K}^{+}\right) \times 100}{\left(\mathrm{Na}^{+}+\mathrm{K}^{+}+\mathrm{Ca}^{2+}+\mathrm{Mg}^{2+}\right)}
$$

where the concentrations are in meq/L.

Based on SSP values, 70\% of analyzed water samples belong to "Excellent" class while 30\% belong to "Good to Permissible" class during dry season. In wet season, $90 \%$ of analyzed water samples fall under "Excellent" class while only $10 \%$ falls under "Good to Permissible" class (Table 13). High SSP values may mean stunted plant growth and reduce soil permeability [23].

Residual Sodium BiCarbonate (RSBC): The concentration of bicarbonate and carbonate in water influences the suitability of water for irrigation purpose. Land irrigated with high RSBC water becomes infertile due to deposition of sodium carbonate [27]. RSBC is calculated [28] as:

$$
\mathrm{RSBC}=\left[\left(\mathrm{HCO}_{3}^{-}\right)-\left(\mathrm{Ca}^{+}\right)\right]
$$

where ions are expressed in Meq/L.

During dry season, $80 \%$ of water samples fall under "Fair" category while 20\% falls under "Good" category. During wet season, the percentage of groundwater samples under "Fair" class has increased to $90 \%$ while the remaining $10 \%$ falls under "Good" category for irrigation purpose. The classification of groundwater based on RSBC value is shown in Table 14.

Kelly's Ratio: Kelly's ratio is calculated by the numerical formula [29]:

$$
\mathrm{KR}=\frac{\mathrm{Na}^{+}}{\left(\mathrm{Ca}^{2+}+\mathrm{Mg}^{2+}\right)}
$$

KR values of 1 or $<1$ is an indication of good quality water for irrigation purpose while KR of $>1$ is unsuitable 
Table 11. Alkalinity hazard classes based on SAR values.

\begin{tabular}{ccccc}
\hline Water class & Alkalinity hazard & SAR values & \% during dry season & \% during wet season \\
\hline Excellent & $\mathrm{S}_{1}$ & $<10$ & 100 & 100 \\
Good & $\mathrm{S}_{2}$ & $10-18$ & - & - \\
Doubtful & $\mathrm{S}_{3}$ & $18-26$ & - & - \\
Unsuitable & $\mathrm{S}_{4}$ & $>26$ & - & - \\
\hline
\end{tabular}

Table 12. Quality of irrigation water based on PI values.

\begin{tabular}{cccc}
\hline Water class & PI values & \% during dry season & \% during wet season \\
\hline Excellent & $>75$ & 100 & 100 \\
Good to permissible & $75-25$ & - & - \\
Doubtful to unsuitable & $<25$ & - & - \\
\hline
\end{tabular}

Table 13. Quality of groundwater based on SSP values.

\begin{tabular}{cccc}
\hline Water class & SSP values & \% during dry season & \% during wet season \\
\hline Excellent & $<60$ & 70 & 90 \\
Good to permissible & $60-75$ & 30 & 10 \\
Doubtful to unsuitable & $>75$ & - & - \\
\hline
\end{tabular}

Table 14. Quality of groundwater based on RSBC values.

\begin{tabular}{cccc}
\hline Water class & RSBC values & \% during dry season & \% during wet season \\
\hline Excellent & $<1.25$ & - & - \\
Good to permissible & $1.25-2.5$ & 20 & 10 \\
Doubtful to unsuitable & $>2.5$ & 80 & 90 \\
\hline
\end{tabular}

for agricultural purpose due to alkali hazard [25]. Based on this classification, the KR values of groundwater samples in dry season shows that $60 \%$ belong to "Good" class while $40 \%$ belong to "Unsuitable" class for irrigation purpose. During Wet season, 90\% of analyzed groundwater samples belong to "Good” class while only 10\% belongs to "Unsuitable” class for irrigation use (Table 15).

Total Dissolved Solids (TDS): The TDS concentrations in the groundwater surrounding Aba-Eku dumpsite during dry season range from 74 to $392 \mathrm{mg} / \mathrm{L}$ and 100 to $268 \mathrm{mg} / \mathrm{L}$ during wet season. Based on classification of irrigation water with respect to TDS [30], all the analyzed groundwater samples belongs to "best quality water" status for irrigation purpose as their TDS values lie below $1000 \mathrm{mg} / \mathrm{L}$.

\section{Conclusion}

The major ions in groundwater samples were found to be within the permissible limits of WHO and NSDWQ, thus suitable for domestic purpose. However, water from location 5 showed higher values of concentration of most parameters than other locations due to its nearness to the landfill. Generally, the groundwater quality of the study area in both seasons based on the interpretation of hydrochemical analyses is hard, fresh and alkaline in nature. The dominant groundwater type in both seasons was $\mathrm{CaHCO}_{3}$ type. Alkaline earth $\left(\mathrm{Ca}^{2+} \mathrm{and} \mathrm{Mg}^{2+}\right) \mathrm{ex}^{-}$ ceeds alkalis $\left(\mathrm{Na}^{+}\right.$and $\left.\mathrm{K}^{+}\right)$and weak acids $\left(\mathrm{HCO}_{3}^{-}\right.$and $\left.\mathrm{CO}_{3}^{2-}\right)$ exceed strong acids $\left(\mathrm{Cl}^{-}\right.$and $\left.\mathrm{SO}_{4}^{2-}\right)$. There is a strong association between EC and TDS, $\mathrm{Cl}^{-}, \mathrm{TH}$ and $\mathrm{Na}^{+}$during both seasons. The suitability of groundwater for irrigation purpose based on calculated irrigation parameters showed that sizeable number of the groundwater 
Table 15. Quality of groundwater based on KR values.

\begin{tabular}{cccc}
\hline Range of KR & Water class & \% during dry season & \% during wet season \\
\hline$<1$ or 1 & Good & 60 & 90 \\
$>1$ & Unsuitable & 40 & 10 \\
\hline
\end{tabular}

samples will neither cause salinity hazards nor have adverse effects on the soil properties and thus suitable for irrigation needs.

\section{Acknowledgements}

The authors are grateful to the Institute of Food Security, Environmental Resources and Agricultural Research (IFSERAR) of Federal University of Agriculture, Abeokuta (FUNAAB), Nigeria for funding part of this research work through research grant no: FUNAAB/IFSERAR/IRG100.

\section{References}

[1] Subramani, T., Elango, L. and Damodarasamy, S.R. (2005) Groundwater Quality and Its Suitability for Drinking and Agricultural Use in Chithar River Basin, Tamil Nadu, India. Environmental Geology, 47, 1099-1110. http://dx.doi.org/10.1007/s00254-005-1243-0

[2] Rizwan, R. and Gurdeep, S. (2010) Assessment of Groundater Quality Status by Using Water Quality Index Method in Orissa, India. World Applied Sciences Journal, 9, 1392-1397.

[3] Ramakrishnaiah, C.R., Sadashivaiah, C. and Ranganna, G. (2009) Assessment of Water Quality Index for Groundwater in Tunikur Taluk, Karnataka State, India. E-Journal of Chemistry, 6, 523-530.

[4] Wilcox, L.V. (1948) The Quality Water for Irrigation Use. Bulletin of the US Department of Agriculture, 40 p.

[5] Matias, M.S, da Silva, M.M., Ferreira, P. and Ramalho, E. (1994) A Geophysical and Hydrogeological Study of Aquifers Contamination by a Landfill. Journal of Applied Geophysics, 32, 155-162. http://dx.doi.org/10.1016/0926-9851(94)90017-5

[6] Ikem, A., Osibanjo, O., Sridliar, M.K.C. and Sobande, A. (2002) Evaluation of Groundwater Quality Characteristics near Two Waste Sites in Ibadan and Lagos, Nigeria. Water, Air and Soil Pollution, 140, 307-333. http://dx.doi.org/10.1023/A:1020165403531

[7] Tijani, M.N., Onibalusi, S.O. and Olatunji, A.S. (2002) Hydrochemical and Environmental Impact Assessment of Orita Aperin Waste Dumpsite, Ibadan, Southwestern, Nigeria. Water Resources, 13, 78-84.

[8] Armah, F.A., Luginaah, I. and Ason, B. (2012) Water Quality Index in the Tarkwa Gold Mining Area in Ghana. Journal of Transdisciplinary Environmental Studies, 11, 1-15.

[9] Sadashivaiah, C., Ramakrishnaiah, C.R. and Rangana, G. (2008) Hydrochemical Analysis and Evaluation of Groundwater Quality in Tumkur Taluk, Karnataka State, India. International Journal of Environmental Research and Public Health, 5, 158-164. http://dx.doi.org/10.3390/ijerph5030158

[10] Ramesh, K. and Bhuvana, J.P. (2012) Hydrochemical Characteristics of Groundwater for Domestic and Irrigation Purpose in Periyakulami Taluk of Theni District, Tamilu, Nadu, India. International Journal of Environmental Science, 1, $19-27$.

[11] Sujatha, D. and Rajeswara Reddy, B. (2003) Quality Characterization of Groundwater in the South-Eastern Part of the Ranga Reddy District, Andra Pradesh, India. Journal of Environmental Radioactivity, 44, 579-586. http://dx.doi.org/10.1007/s00254-003-0794-1

[12] Rahaman, M.A. (1976) Review of Basement Geology of the Southwestern Nigeria. Elizabethan Publishing Company, Lagos, 14-48.

[13] Okunlola, O.A., Adeigbe, O.C. and Oluwatoke, O.O. (2009) Compositional and Petrogenetic Features of Schitose Rocks of Ibadan Area, Southwestern Nigeria. Earth Sciences Research Journal, 13, 29-43.

[14] Sawyer, G.N. and McCarthy, D.L. (1967) Chemistry of Sanitary Engineers. 2nd Edition, McGraw Hill, New York, 518.

[15] Freeze, R.A. and Cherry, J.A. (1979) Groundwater. Prentice-Hall Inc., Englewood Cliffs, 604.

[16] WHO (2007) Water for Pharmaceutical Use in Quality Assurance of Pharmaceuticals. A Compendium of Guidelines and Related Materials, 2nd Updated Edition, World Health Organization, Geneva, 170-187. 
[17] NSDWQ (2007) Nigerian Standard for Drinking Water Quality. NIS 554, Standard Organization of Nigeria, Lagos, 30.

[18] Hem, J.D. (1992) Study and Interpretation of the Chemical Characteristics of Natural Water. US Government Print Office, Washington DC.

[19] Piper, A.M. (1944) A Graphical Procedure in the Geochemical Interpretation of Water Analysis. Transactions of American Geographical Union, 25, 914-923. http://dx.doi.org/10.1029/TR025i006p00914

[20] Back, W. (1966) US Geological Survey. 42.

[21] Saleh, A., Al-Ruwaih, F. and Shehata, M. (1999) Hydrogeochemical Processes Operating within the Main Aquifers of Kuwait. Journal of Arid Environments, 42, 195-209. http://dx.doi.org/10.1006/jare.1999.0511

[22] Karanth, K.R. (1987) Groundwater Assessment, Development and Management. Tata McGraw Hill, New Delhi, 720.

[23] Joshi, D.M., Kumar, A. and Agrawal, N. (2009) Assessment of the Irrigation Water Quality of River Ganga in Haridwar District. Indian Journal of Chemistry, 2, 285-292.

[24] Ayers, R.S. and Westcot, D.W. (1985) Water Quality for Agriculture FAO Irrigation and Drain. Paper No. 29 , 1-109.

[25] Ragunath, H.M. (1987) Groundwater. Wiley Eastern Ltd., New Delhi, 563.

[26] Todd, D.K. (1995) Groundwater Hydrology. 3rd Edition, Wiley and Sons Inc., New York.

[27] Eaton, E.M. (1950) Significance of Carbonate in Irrigation Water. Soil Science, 69, 123-133. http://dx.doi.org/10.1097/00010694-195002000-00004

[28] Gupta, S.K. and Gupta, I.C. (1987) Management of Saline Soils and Water. Oxford and IBH Publication Company, New Delhi, 399.

[29] Kelly, W.P. (1963) Use of Saline Irrigation Water. Soil Science, 95, 355-391.

[30] Wilcox, L.V. (1955) Classification and Use of Irrigation Water. US Department of Agriculture, Circular 969, Washington DC. 
Scientific Research Publishing (SCIRP) is one of the largest Open Access journal publishers. It is currently publishing more than 200 open access, online, peer-reviewed journals covering a wide range of academic disciplines. SCIRP serves the worldwide academic communities and contributes to the progress and application of science with its publication.

Other selected journals from SCIRP are listed as below. Submit your manuscript to us via either submit@scirp.org or Online Submission Portal.
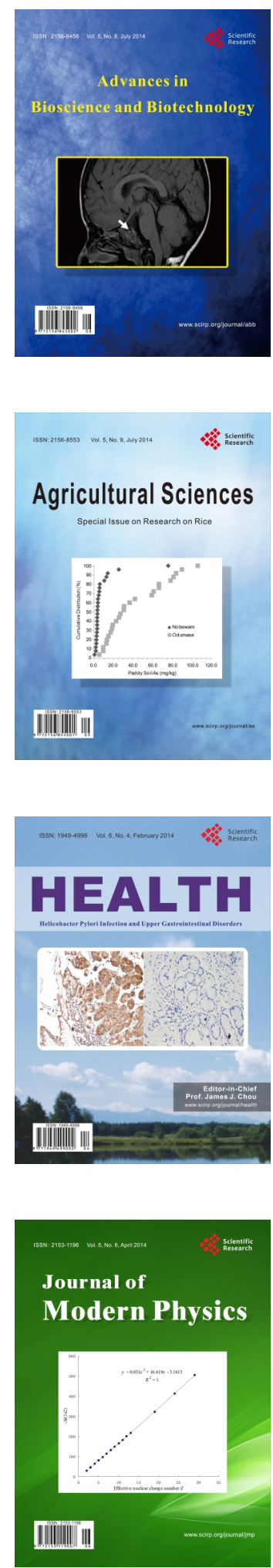
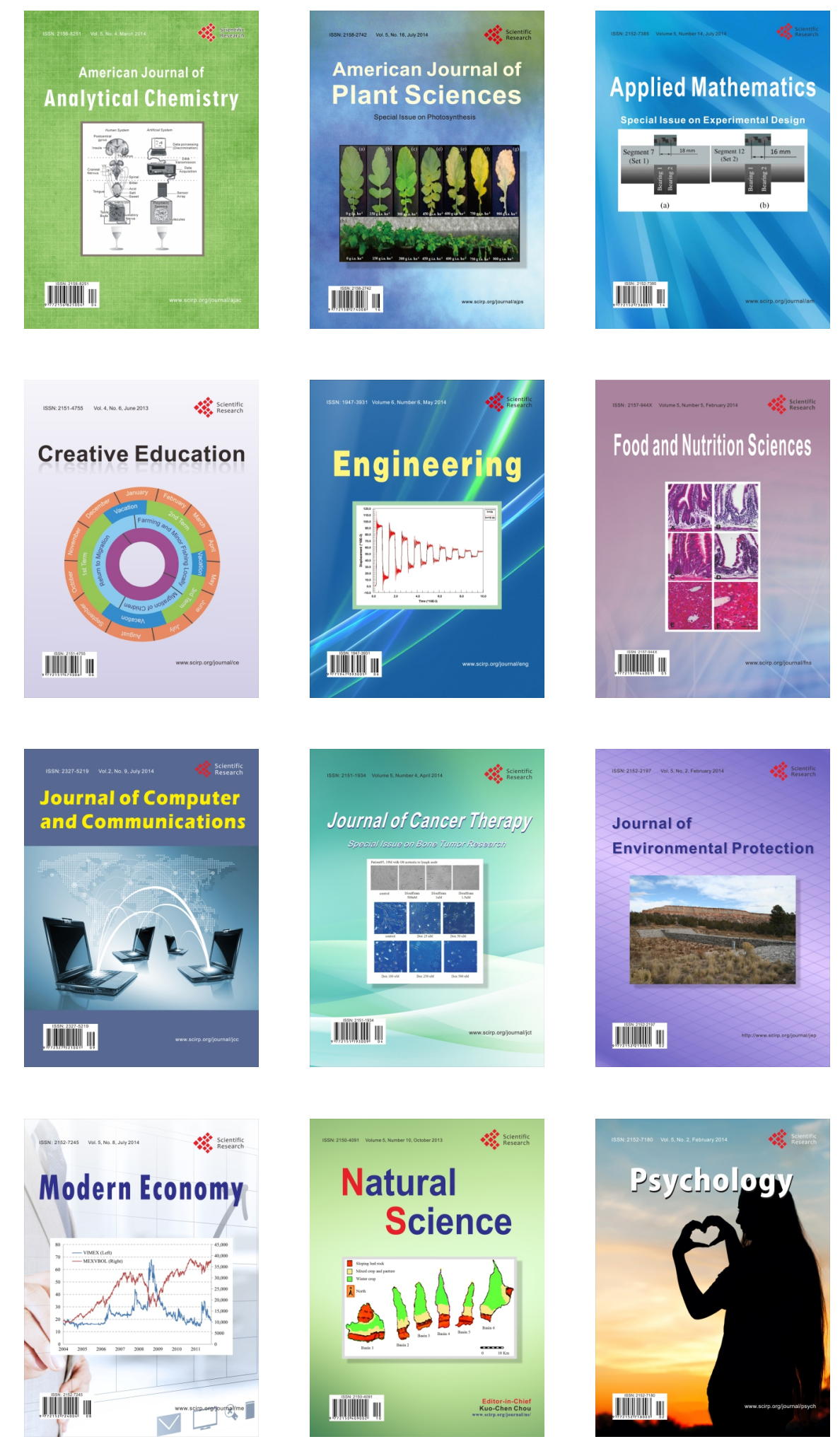